\title{
Agriculture Resource Management Planning on the Wind River Indian Reservation: An Integrative Approach
}

\author{
Ginger B. Paige ${ }^{1 *}$, William J. Gribb ${ }^{2}$, Roger H. Coupal ${ }^{3}$ \\ ${ }^{1}$ Department of Ecosystem Science and Management, College of Agriculture and Natural Resources, University of Wyoming, \\ Laramie, WY, USA \\ ${ }^{2}$ Department of Geography, College of Arts and Sciences, University of Wyoming, Laramie, WY, USA \\ ${ }^{3}$ Department of Agricultural and Applied Economics, College of Agriculture and Natural Resources, University of Wyoming, \\ Laramie, WY, USA \\ Email: *gpaige@uwyo.edu, planning@uwyo.edu,coupal@uwyo.edu
}

How to cite this paper: Paige, G. B., Gribb, W. J., \& Coupal, R. H. (2019). Agriculture Resource Management Planning on the Wind River Indian Reservation: An Integrative Approach. Journal of Geoscience and Environment Protection, 7, 206-221. https://doi.org/10.4236/gep.2019.712015

Received: October 17, 2019

Accepted: December 28, 2019

Published: December 31, 2019

Copyright (C) 2019 by author(s) and Scientific Research Publishing Inc. This work is licensed under the Creative Commons Attribution International License (CC BY 4.0)

http://creativecommons.org/licenses/by/4.0/

\begin{abstract}
The Wind River Indian Reservation undertook the development of an agricultural resource management plan in 2015. The reservation is $8903 \mathrm{sq} \cdot \mathrm{km}$ of which $63 \%$ is in crop and grazing lands. This project's aim was to create a community-based integrated plan. A series of community meetings identified 83 issues and topics relating to agricultural development on the reservation. Using information from community meetings, the final agricultural resource management plan consists of 9 major elements, with 12 goals, 46 objectives and 88 policies. Three key issues are addressed in the plan: provide the reservation with a plan that leads to self-management of their agricultural resources; integrate the major agricultural elements as defined by the community into policies; and, create a governance structure that fosters agricultural development into the future.
\end{abstract}

\section{Keywords}

Agricultural Planning, Integrative, Wind River Indian Reservation, Community-Based

\section{Introduction}

In the United States, agricultural lands account for $39.8 \%\left(3,643,0510 \mathrm{~km}^{2}\right)$ of the total area, 9,147,593 sq.km (Census Bureau, 2017). The amount of land in agriculture has been decreasing; since 1997 farmland has decreased by $5.7 \%$ or over $220,714 \mathrm{~km}^{2}$, an area roughly the size of Utah. At this rate, by 2050 the 
United States will lose another $287,981 \mathrm{~km}^{2}$ of farmland. Areas in the western United States are experiencing even more rapid changes in arable lands. The amount of agricultural land on western Indigenous lands has decreased by $2.2 \%$ over the last five years, and accounts for only $64 \%$ of their total lands, approximately $199,468 \mathrm{~km}^{2}$. These losses, however, will be exacerbated by the impacts of climate change (Walthall et al., 2012). An important factor in mitigating the losses to agricultural production, both crops and livestock, is better local/regional management and future planning.

To make agricultural production sustainable into the future, the long-term productivity of agricultural lands and the changing consumption and land use patterns need to more equitably benefit the entire community, from farmers to consumers (Gliessman, 1998). This entails a knowledge of the agricultural ecosystem and the logistics of the agricultural economy. However, in some situations local cultural knowledge is another important component to managing agricultural production. Sundriyal \& Dollo (2013) provide an example of this in an integrated agricultural and allied natural resource study of peoples in northeast India. They found a higher level of ecological and economic efficiency, which increased community self-sufficiency. Zaferatos (2015) believes that it is imperative to understand the tribal cultural characteristics for Native American reservation planning. Both of these are critical for this agricultural resource management plan project on the Wind River Indian Reservation.

There are many barriers to agricultural development on Indigenous lands. Singletary, Emm, Brummer, Hill, Lewis, \& Hebb (2015) identified several such barriers including geographic isolation, socio-political marginalization, marginal productivity of lands, lack of operating capital, shortage of human capital necessary to manage lands effectively, and land tenure. The right and ability to govern the people and lands of a reservation has always been held by the different tribal groups (Pevar, 2012). However, the execution of this right has been controlled by the federal government, either through court decisions or legislative action. The US Constitution and the US Supreme Court recognized tribal groups as sovereign by equating them with foreign powers through treaties (US Const., Art.II, \$2), and states with the commerce clause (US Const., Art. I, \$8; Wilkins, 1997). Two legislative acts strengthened tribal sovereignty and administration, the Indian Reorganization Act of 1934 (P. L. 73-383) and the Indian Self-Determination and Education Assistance Act of 1975 (P. L. 93-638). Both acts enhanced the ability of tribal governments to administer, legislate and enforce tribal governance. Since the 1960s, Congress has promoted and supported tribal programs that heighten tribal sovereignty (Pevar, 2012). It is believed that once tribal entities have control over their practice of sovereignty, sustainable development can take place (Fletcher, 2011). Self-governance leads to management of resources that reflects local interests, perceptions and issues and holds the tribal government responsible for their actions. The development of an agricultural plan with the participation and direct input by reservation citizens allows tribes to develop and investigate strategies to overcome many of the identified barriers. 
In 2014, the two tribes of the Wind River Indian Reservation (WRIR) in central Wyoming, the Eastern Shoshone and Northern Arapaho, received a grant to develop an Agricultural Resource Management Plan (ARMP) under AIARMA the American Indian Agricultural Resource Management Act of 1993 (P. L. 103-177). An agricultural resource management plan can take on several different forms, a stand-alone plan or be part of a comprehensive or environmental plan. For example, the Colville Reservation (2015) (www.colvilletribe.com) created a stand-alone agricultural resource management plan. Whereas, the Pyramid Lake Reservation (2011) (http://plpt.nsn.us/) and the Confederated Salish and Kootenai Tribes (2019) (http://tribalnations.mt.gov/cskt) incorporated agricultural management within their comprehensive plans. The Navajo Nation (2019) formed a Department of Agriculture under the Division of Natural Resources and outlined their agricultural management within that framework

(http://www.agriculture.navajo-nsn.gov/ranches.html).

The intent of the AIARMA is for local tribal management to determine the future direction of agriculture on a reservation and have governance managed by the reservation. For the WRIR, the tribes wanted the ARMP to follow the prescribed process detailed in the AIARMA. As such, an ARMP for the WRIR developed following the guidelines of AIARMA and signed by the Secretary of Interior would allow the two tribes of the Reservation to determine the future direction of agriculture on the reservation and have governance managed by the people of the reservation.

The specific objectives for developing the WRIR ARMP were to:

1) Develop a framework and mechanisms for both tribes to jointly control agriculture and natural resource management on the Reservation;

2) Develop a wholistic plan that promotes integrated management of agriculture and natural resources across all sectors of the Reservation; and

3) Build a platform for improving and promoting agriculture and natural resource management for all the people, including agriculture economic growth; water resource management; and educational opportunities.

We highlight and illustrate the processes and components that were required to develop a comprehensive and integrated agriculture and natural resource management plan that 1 ) follows the vision of the two tribes regarding the future of agriculture within the communities on the Reservation and 2) directly addresses the identified needs and issues regarding agriculture and natural resource development and management.

\section{Background}

The Wind River Indian Reservation encompasses $8903 \mathrm{~km}^{2}$ in central Wyoming (Figure 1). The lands include the eastern slopes of the Wind River Range and the Wind River Basin bisected by the Little and Big Wind Rivers (Brown, 1993). The Reservation has considerable natural resources and natural assets that generate economic and cultural values for the region. Located in the rainshadow of the Wind River mountain range, the Reservation receives approximately $30.5 \mathrm{~cm}$ 


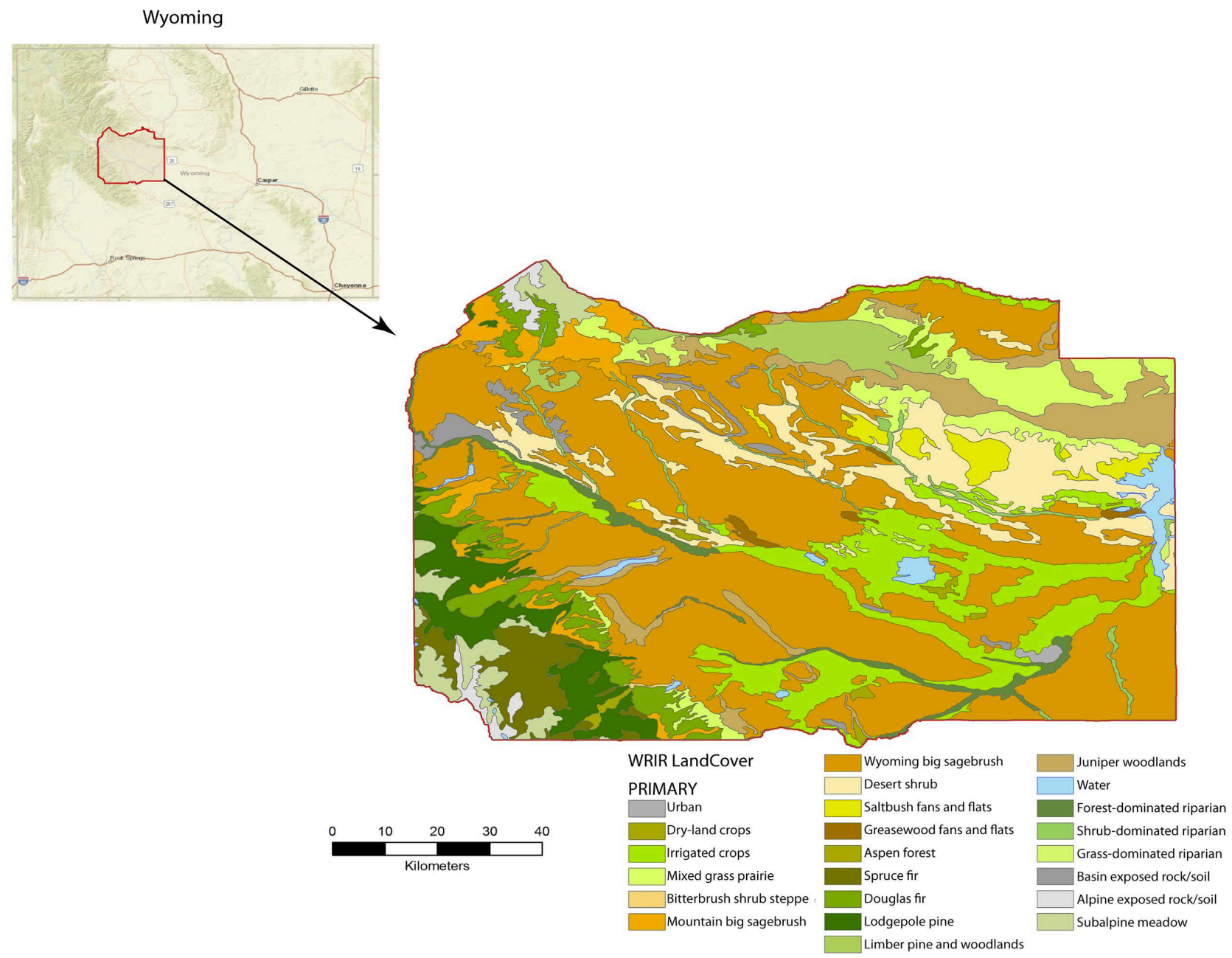

Figure 1. Land cover on the Wind River Indian Reservation, Wyoming, USA (data are from USDA (2012) the National Land Inventory, NRCS 2012).

of precipitation per year, with snowfall ranging from 28 to $229 \mathrm{~cm}$ per year. Overall there is approximately $346 \mathrm{~km}^{2}$ of prime agricultural lands with over 962 sq. $\mathrm{km}$. in assorted crops of hay and other grains. Over $61 \%\left(5453 \mathrm{~km}^{2}\right)$ of the reservation can be classified as grazing lands and is in prairie grass, sagebrush and desert shrub (National Resource Inventory, 2012; Figure 1). The Wind River Reservation is unique in that two different tribal groups reside on the reservation, the Eastern Shoshone and the Northern Arapaho. The overall population on the reservation is 27,088 (Census Bureau, 2017), with approximately 9400 Northern Arapaho and 3500 Eastern Shoshone (Hazlitt, Nowlin, \& Phipps, 2013).

Fortunately for the Wind River Indian Reservation most of the land is in tribal trust or tribal allotted lands $\left(7331 \mathrm{~km}^{2} ; 80.3 \%\right)$ and is not pock-marked by fee simple lands/privately-owned lands $\left(1798 \mathrm{~km}^{2} ; 19.7 \%\right)$. The tribal trust and allotted lands are mainly congruent throughout the reservation with the fee simple lands concentrated along the two main rivers and the southern portion of the reservation (Figure 2). Tribal trust lands are the responsibility of the US government to protect yet can be managed and controlled by the tribal council(s) 


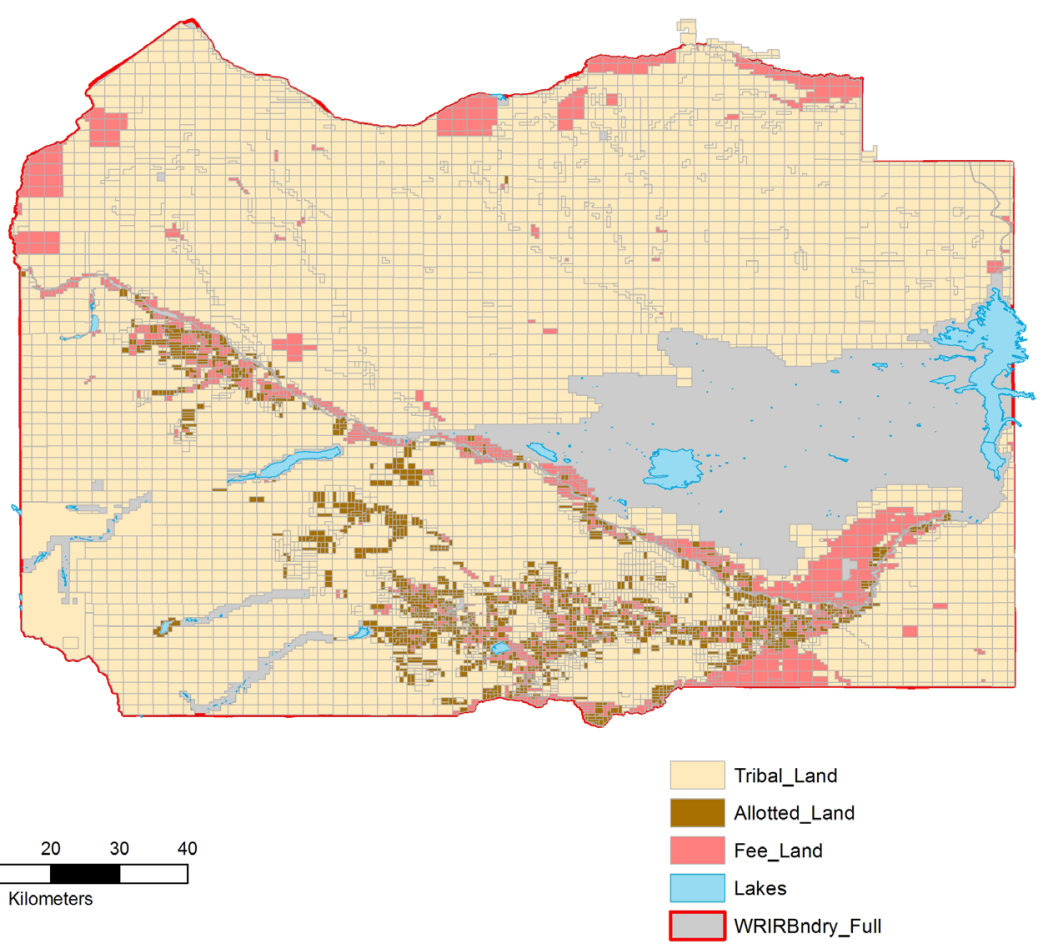

Figure 2. Land ownership on the Wind River Indian Reservation (data (n.d.) from the BIA, Office of Realty, Ft. Washakie, WY).

(Pevar, 2012). Tribal-Allotted lands are parcels that were transferred to a tribal member under General Allotment Act of 1887 (also known as the Dawes Act). Fee simple land titles are held by individuals that may or may not be affiliated with a tribal group and are not under the direct jurisdiction of the two tribal councils, but under the management of the local government.

Agricultural management on the Wind River Indian Reservation is currently conducted by the Bureau of Indian Affairs (BIA) through the Branch of Agriculture and Rangeland Management (US Department of Interior, 2019). This branch is responsible for the following activities: inventory, farm and range planning, rangeland improvements, rangeland protection, leasing and permitting services, contract monitoring, agricultural extension and noxious weed eradication (www.bia.gov/trustservices). Each agency office provides the services to conduct the different activities. In the case of the Wind River Indian Reservation full time personnel are available for range management, soil resources, leasing/permitting, and invasive species control.

WRIR has important agriculture and natural resources, land and water, for which integrated management approaches can be implemented to benefit the tribes and their resource base. Coupled with the capacity to enhance agricultural resources and expertise, the two tribes have the potential to enhance income and employment opportunities. The potential to develop a leasing and land use system that reduces the costs of risk management and increases agricultural opportunities relative to the current BIA approach is a current identified need. Cur- 
rently the Reservation has $962 \mathrm{~km}^{2}$ of irrigated crop land, making up approximately $10.5 \%$ of the total land area of the reservation, $8903 \mathrm{~km}^{2}$. Another $31 \mathrm{~km}^{2}$ are dryland crops and $15 \mathrm{~km}^{2}$ of human settlements. Fractionation of land ownership is not as significant as in many other reservations and so land management is expected to be easier than otherwise might be. Trust and Allotted trust land comprise $79 \%$ of available land, the remainder of agricultural land is fee simple. The 2017 Agriculture census indicates that the average farm size on the Reservation is over 1888 ha; however, more than $62 \%$ of the farms operated by Native Americans are less than 202 ha (USDA, 2019).

Water resources, and their management, are considered one of the most important agricultural and natural resource on the Reservation by the Eastern Shoshone and Northern Arapahoe Tribes. An overall goal of the tribes is to manage water availability for agricultural users with a management system that recognizes the Wind River Water Code and can adjust to long and short-term weather and climatic conditions.

There are several critical issues facing the Reservation regarding water resource management. First, the US Supreme Court (1989) confirmed the Reservation's rights to nearly $616.7 \mathrm{~m}$ cubic meters (500,000 acre-feet) of water per year, with $257.8 \mathrm{~m}$ cubic meters (209,000 acre-feet) of that amount allotted based on specific future irrigation projects (Wyoming v. United States, 492 US 938, 110 S. Ct. 28, 106 L. Ed. 2d 639 (US Supreme Court, 1989)). A question moving forward is use of this "futures" water, including development of efficient delivery of this water to irrigable land. This is specifically critical due to the lack of maintenance and improvement of irrigation infrastructure in the major existing irrigation projects over the past decades (US Senate, 2014). Another critical issue for the WRIR is that under the court decision the tribes' reserved rights do not include groundwater; most ground water resources on the Reservation are still considered waters of the state. The tribes in conjunction with the Water Board have recognized to need to be able to control and directly manage water resources on the WRIR.

Similar to land resources there are significant water resources that can be economically developed to support irrigated agriculture. The long-term average flow into the reservation in June for two of the major drainages east from the Wind River Mountains, the Wind and Little Wind Rivers generate $281.5 \mathrm{~m}$ cubic meters (228,201 acre-ft). The arid climate requires a considerable dependency on irrigation. Currently, on-reservation irrigation use is comprised of 5726 ha from the Wind River drainage irrigating serving the Crowheart, Johnstown, and Left Hand Units. The Little Wind River serves a total of 8900 to 9900 ha in the Little Wind Unit. Total current irrigated capacity is as high as 102,264 ha, 15 percent of total trust lands.

Wildlife management on the Reservation is concerned with the interaction between wildlife, livestock and the changes to their habitat due to agricultural practices. The diversity of wildlife habitats on the Reservation includes over 200 
species of mammals and birds alone that either have a permanent home on the Reservation or use the Reservation as part of their migratory pattern. In addition, the wetlands, riparian areas and stream channels are habitats for a range of aquatic and semi-aquatic species of importance. The tribes are currently reintroducing Bison on the Reservation (US Fish and Wildlife Service, 2017; Bonogofsky, 2017), but are also very concerned about the large numbers of wild horses using upland resources

Both tribes identified the following overarching issues that could be addressed by developing an integrated ARMP:

1) Lack of direct control over resource management by local tribes; no ability to affect policies that impact agriculture and natural resource management.

2) Siloed management of the different components-no integration across sectors.

3) Current agricultural resource management approaches do not promote agricultural development on the WRIR.

\section{Process and Results}

Development of the ARMP was a joint effort between the Eastern Shoshone and Northern Arapaho tribal councils, the WRIR Tribal Water Engineer's Office, and the University of Wyoming. Two tribal committees, the Water Board and the Agricultural Producers Committee, were the lead community organizers for forming the ARMP committee and guiding the process. The ARMP was developed using the rational planning process (So \& Getzel, 1988; Figure 3). Modifications to this process allowed for a more integrative and adaptive planning process (Lachapelle, McCool, \& Patterson, 2003; Daher \& Mohtar, 2015). This included developing overlapping goals, objective and policies between identified issues and topics and including flexibility in policies recommended to address issues and topics. In general, a plan takes 5 - 8 years to be completed. The first $2-3$ years establish the community vision, set goals and objectives and develop policies. The plan is then implemented by the decision-makers, a 2-year process, followed by $2-3$ years of monitoring the plan to determine if the policies were properly implemented. Finally, 2 years are needed to evaluate the plan to ensure it meets the community vision and accomplishes the goals and objectives (So \& Getzel, 1988).

Reservation planning adds an additional factor that needed to be incorporated into each component of the process, the cultural characteristics of the Native American community. As espoused by Zaferatos (2015), tribal planning is based on community participation and the incorporation of the tribes spiritual, cultural, economic and political systems. As illustrated in Figure 4, the first component was to develop community-wide goals based on the mission or vision for the plan. For the WRIR an introductory meeting with members of the ARMP committee comprised of members from both tribes from the AG producers and the Tribal water Board and included identified stakeholders (e.g., local BIA, 


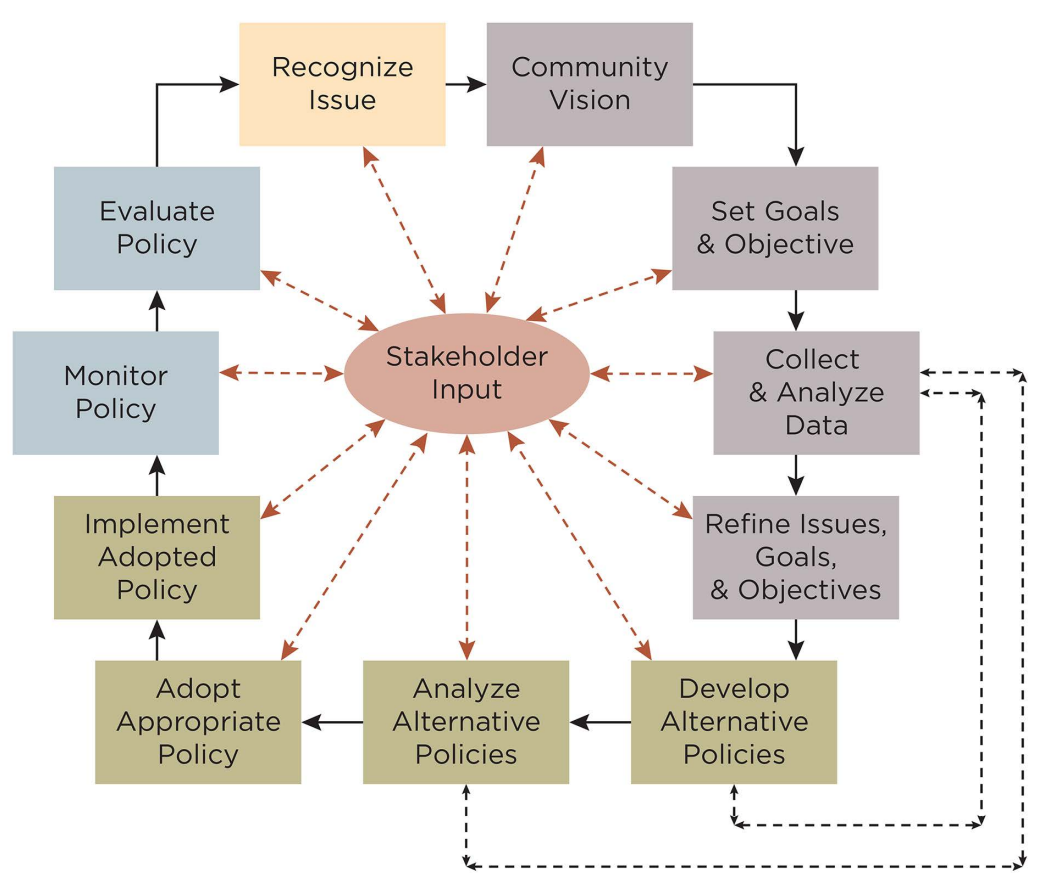

Figure 3. Rational planning process used to develop WRIR ARMP (modified So \& Getzel, 1988).

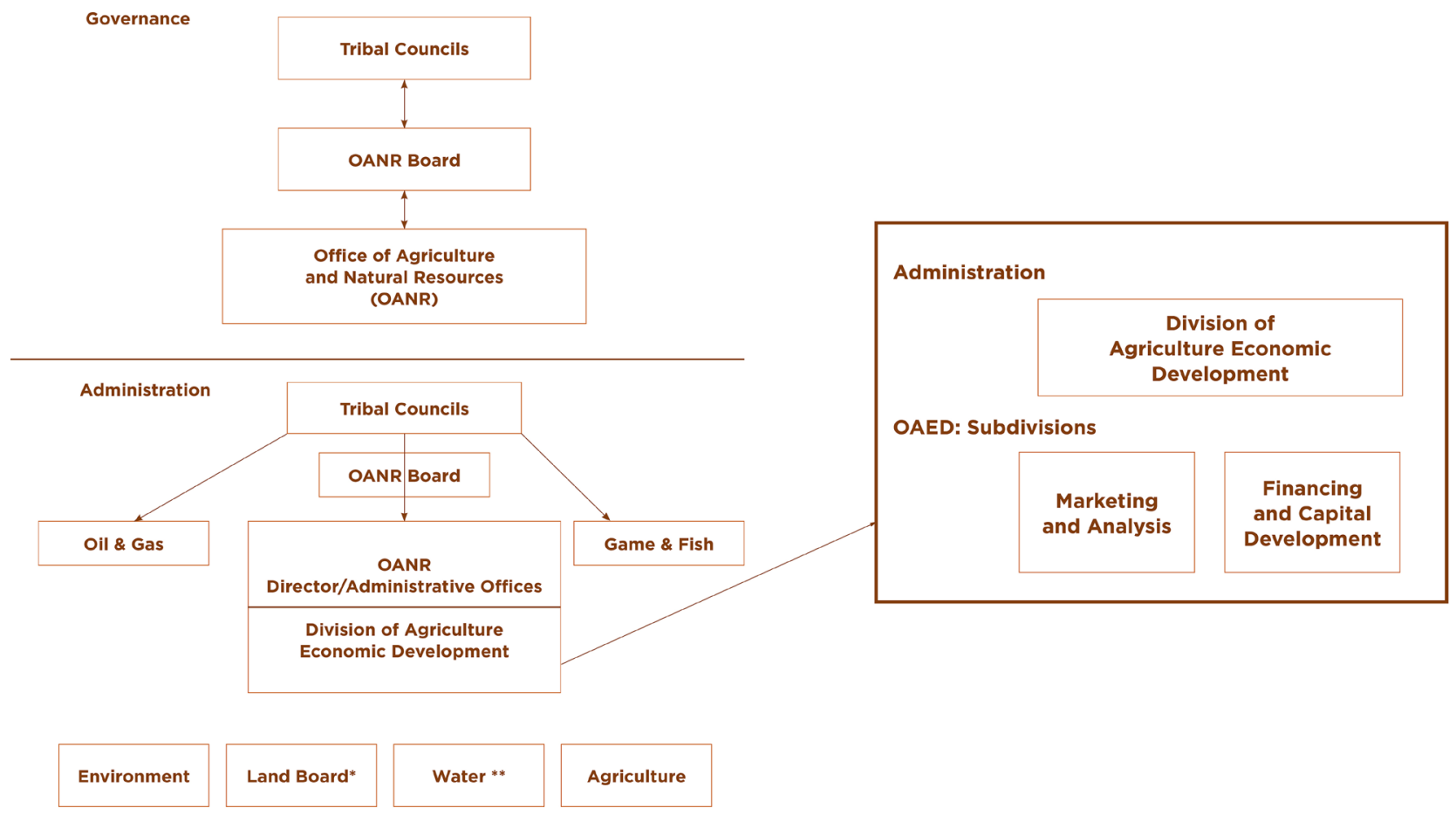

Figure 4. The proposed office of agriculture and natural resources and division of agriculture economic development for the WRIR. ${ }^{*}$ The Land Board (and Land Code) need to be developed. ${ }^{*}$ The Water Board already exists.

Wyoming Game \& Fish, US Fish and Wildlife Service, local University of Wyoming Extension, and Tribal, local and state representatives) was held in the fall of 2015. The goal of the meeting, facilitated by University of Wyoming, was to de- 
termine what type of plan the Reservation wanted, how to develop the plan, and identify the vision for the plan. An underlying expectation highlighted by the ARMP committee was the potential extension of sovereignty that the plan would provide to the tribes as stated in the AIARMA. The committee decided to develop a community-based integrative plan that included water, agricultural economic development, land rights, and the use of Geographic Information Systems to provide access to basic information. From the first committee meetings, the plan's vision was developed, “a viable, self-directed and sustainable agricultural economy that enhances the education, health, natural resources, traditions and culture of our native people" (Wind River Indian Reservation, 2018; tribalwaterengineers.org).

The planning process was centered on community participation, and to accomplish this a series of meetings were held at the key communities of Arapahoe, Crowheart, Ethete and Ft. Washakie across the Reservation. Organized by the ARMP committee, the community meetings were designed to elicit issues, topics of concern, and the direction of the ARMP based on the vision statement. A total of 83 topics and issues were identified during the community meetings. Working with ARMP committees, the identified issues and concerns were categorized into nine focused elements; agricultural management, water, agricultural economy, cropland productivity, rangeland productivity, land leasing, land tenure, wildlife management, and agricultural and natural resource information management.

The next component of the planning process was to create the plan with goals and objectives based on the topics, issues and concerns from community and working group meetings. Again, a series of meetings with the ARMP committee produced the initial broad-statement goals of the ARMP. For the nine elements, a total of 12 goals were established. The third component in the planning process was to identify the major objectives for each goal. Objectives are measurement-based statements that can be evaluated for their completion. The ARMP committee formulated the objectives for each goal for each element. Overall, 46 objectives were developed to address the identified goals. During this phase, a second round of community meetings were held to present the objectives and to create new objectives or modify the initial statements based on community input.

The fourth component of the planning process was to construct policies that can be implemented to meet the objectives and goals. Policies are directed courses of action to deal with a problem or matter of concern (Anderson, 2003). The policy statements were evaluated as to their administrative, economic, technical and/or political feasibility as to the policy being accepted and implemented (Patton \& Swawicki, 1993). A fifth aspect for tribal planning is its feasibility in a tribal cultural context (Zaferatos, 2015). Underlying the actions taken by any policy are the three aspects identified in the Wind River vision statement; that it must be sustainable, continue the traditions and culture, and be integrative as it contributes to the ARMP. Eighty-eight policies were developed during the 
process. Each policy was debated based on its feasibility relative to the five criteria of administrative, economic, technical, cultural, and political attainment. Besides the five feasibility criteria, the sustainability aspects of the policy were discussed in terms of environmental soundness and social/cultural justice (Valentin \& Spangenberg, 2000). The feasibility and sustainability were evaluated not specifically using data analysis, but by the professional, traditional, and practical experiences of the committee members and University of Wyoming facilitation team. The cultural and traditional ways of the Eastern Shoshone and Northern Arapaho were integrated into the policy statements based on the committee tribal members' input. Because of the mix of tribal participation in the committee, both tribal groups had the opportunity to adjust goals, objectives and policies to accommodate their cultural and traditional practices.

The resulting WRIR Agriculture Resource Management plan (www.tribalwaterengineers.org), consisting of the 12 identified goals, 46 objectives, and 88 policies was presented to the WRIR communities for feedback and any clarification. It was then presented to and signed by the two Tribal councils on the Reservation in June 2018. It has been sent to the Regional Office of the BIA and the US Office of the Secretary of Interior.

\section{Discussion}

The integrative aspects of the WRIR ARMP combine the environmental, agricultural, cultural and logistical factors for future development. These are critical components in integrative agricultural and natural resource planning (Petak, 1980; Sundriyal \& Dollo, 2013). Crucial to the implementation of the ARMP is a management system on the WRIR that incorporates the environmental, economic, and cultural aspects of agriculture and natural resource development (Zautra, Hall, \& Murray, 2008). The ARMP identifies the structural components for an Office of Agricultural and Natural Resources (OANR) which integrates these factors (Figure 4). The environmental aspects of the ARMP addresses the administration of water for agriculture based on the Wind River Reservation water code and the interaction between wildlife and livestock. The Wind River Reservation water code identifies the 17 beneficial uses of water based on cultural, economic and traditional ways (Wind River Indian Reservation, 1993). Agricultural economics are integrated into the plan through elements addressing cropland and grazing/rangeland development. All of which are based on the logistics of land leasing and land tenure. These two elements of the plan will follow the Wind River Reservation's land code, once it has been completed.

The proposed Office of Agriculture and Natural Resources is the administrative unit that will oversee the implementation of the ARMP. However, for the ARMP to be successful the OANR needs to be integrated into the Wind River Reservation governance system. The plan addresses and integrates the four factors that are critical to the success of a managing unit within the OANR: 1) a potentially stable governing institution; 2) a governing institution that separates politics from day-to-day business and program management; 3 ) a governing in- 
stitution to take the politics out of dispute resolution; and 4) a governing institution that will provide a bureaucracy that is efficient, effective and operated by professionals (Kalt \& Singer, 2004).

The proposed process for a community member to develop an agricultural project is described in Figure 5. In this scenario, a proposal and business plan are developed and submitted to the OANR. Two sub-offices then evaluate the proposal. The Office of Agricultural Economic Development (OAED) looks at the feasibility of the project at technical/agronomic feasibility and market feasibility. If there is a need for irrigation water, then the Water Board reviews the proposal to identify water use, rights and access potential. This could depend upon both where and what current water uses might be. OAED also works with the individual to build an acceptable proposal that can be defended to outside reviewers and ultimately the Tribal Business Councils. OAED acts as both a technical resource and a small business development center. Once a plan is accepted by both OAED and the Water Board, the Land Board and Water Board develop a contract for the applicant. When the contract is conditionally agreed upon between the applicant both Boards, the Chair of the OANR and applicant all sign the contract.

The leasing system will be designed to facilitate economic sustainability and natural resource conservation for the benefit of the members of the Wind River Tribes. The goal will be to leverage the resources and natural assets for economic development but also encourage conservation and long-term viability. This could mean longer lease terms and allow lessees to reap benefits of any investment in infrastructure and natural capital on their leased property. It is in the interest of both the lessees and the Tribes to foster long-term planning in the use of these lands. The length of these contracts will be based upon both the business plan of the lessee and the OANR Division of Agricultural Economic Development. Goals of the OANR as developed by the working group based upon the

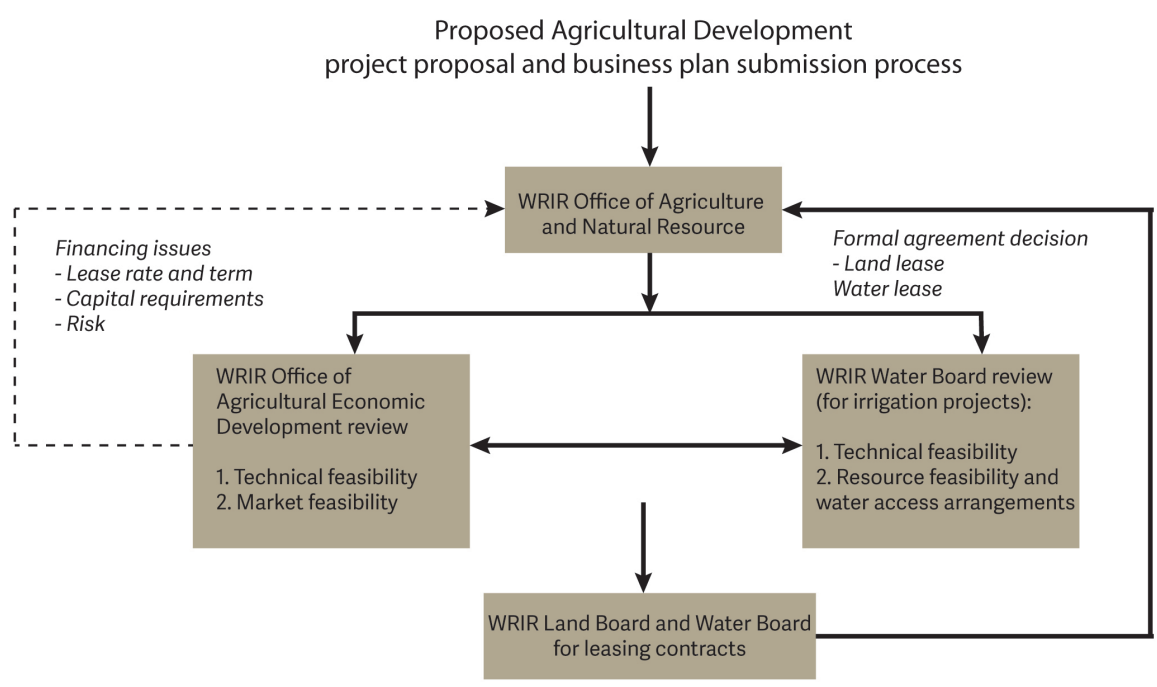

Figure 5. Process that a new agriculture project proposal would follow for consideration. 
community discussion groups are as follows:

- Manage agricultural land leasing for the long-term benefit of tribal members, and the economic and social benefit of farmers and ranchers.

- Manage agricultural land leasing that will benefit the leasees' investment, protect and enhance the natural resources, follow best beneficial land use principles, market fluctuations and provide for long-term sustainable agricultural production.

Wildlife management on the Reservation will also be under the purview of OANR (Figure 4). The responsibility of the office will be to manage the interaction between wildlife, crops, and livestock and the changes to their habitat due to agricultural practices, off-reservation policies that might have spillovers into the reservation, and coordinate with the WRIR Game and Fish Department on community use. A primary goal as defined by the working group and community meetings is to protect and improve wildlife and fish habitats while maintaining and developing rangelands, croplands and riparian areas.

Expanding and enhancing agricultural educational opportunities for the tribes were identified as a high priority for both tribes and is included in the vision statement for the WRIR ARMP. Objectives and policies that directly address and promote educational opportunities for the Reservation are integrated throughout the plan.

The components include:

- Promotion of indigenous stewardship.

- Promotion of K-12 education-e.g., Ag in the Classroom, 4-H programs, FFA (Future farmers of America).

- Develop education program to introduce and implement the FSA and NRCS EQUIP programs (both production and financing).

- Develop scholarship programs for university study in agricultural and animal science.

- Promote agriculture education training opportunities for educators in the classroom (e.g., Wyoming Agriculture in the Classroom or Wyoming Water in the Classroom).

- Establish education program to be implemented through the grazing/rangeland associations for developing resources for long-term economic returns.

The WRIR ARMP was developed following the process stated in the AIARMA of 1993. All of the eight key steps in the AIARMA (Sub-Section C) were completed before it was finalized. The WRIR ARMP process was approved by both the Eastern Shoshone and Northern Arapaho Tribal Councils a major stipulation in AIARMA. An important consideration was that the planning process follow a community-based initiative, this was upheld by holding over 80 community and ARMP committee sessions during the period from December 2014 through June 2018, the three-year period stipulated in AIARMA. The AIARMA stresses that the reservation's agricultural resource management goals and objectives be developed from community meetings; in this case 16 goals and 46 objectives were constructed from these meetings. In addition, the AIARMA proposes 
that a governing body for the implementation of the plan be identified. In this case, the Wind River Reservation did not have a governing body and through the meetings a new Office of Agriculture and Natural Resources was proposed. The AIARMA states that a holistic management plan be developed; the WRIR ARMP integrates nine major elements into the plan including water, croplands, grazing lands, land tenure and land leasing, wildlife, and the use of geo-spatial tools and techniques to monitor and analyze the resource data. The final WRIR ARMP was approved by the two tribal councils and submitted to the Secretary of the Interior and the Bureau of Indian Affairs. Once it is approved by the Department of Interior, the process for implementation, monitoring and evaluation of the plan can commence.

\section{Conclusion}

The Wind River Indian Reservation has been crippled in their efforts to develop and expand their agricultural development. Besides the multiple barriers that reservations must contend with to improve the economic viability of a reservation, the WRIR identified three critical issues that have to be overcome in their agricultural resource management plan:

1) Lack of direct control over resource management by local tribes; no ability to affect policies that impact agriculture and natural resource management;

2) Siloed management of the different components-no integration across sectors; and

3) Current agriculture resource management approaches do not promote agriculture development on the WRIR.

The Eastern Shoshone and Northern Arapaho tribes' agricultural activities on the WRIR have been managed by the BIA. This management includes both crop production and livestock grazing over the whole reservation. With the passage of AIARMA in 1983, a process became available with which tribal groups could take over management of their agricultural resources and activities. This project followed the process outlined in the AIARMA and over three years resulted in the Wind River Indian Reservation Agriculture Resource Management Plan. The plan is community-based and adheres to a vision set by WRIR citizens and major stakeholders. The nine major elements within the ARMP each contain goals, objectives and strategies (policies) that were developed during the community meetings. In addition, the ARMP contains a political model for establishing and organizing an Office of Agriculture and Natural Resource Management that would be responsible for administering the ARMP. After completion of the document, both tribal councils unanimously approved the plan. At this stage final acceptance of the ARMP will be determined by the US Secretary of the Interior or designated authority, after which the ARMP can be administered by the tribes.

In the past, management plans address one problem, e.g., housing, or the plan identified multiple factors and addressed each factor separately. This siloed management scheme neglected the interaction of multiple factors that are influ- 
enced in policy decisions. The Wind River Indian Reservation ARMP has an integrative approach, building its goals, objectives, and policies by overlapping and integrating the environmental, economic, political, land tenure and agricultural production aspects of agriculture as a resource for development and management. The ARMP was developed with each of the nine elements considering the goals, objectives and policies of the other elements. This integration of factors and policies eliminates the silo effect of past management and plans and creates a more holistic agricultural resource management plan.

Finally, the current agricultural resource management is a reactive system. As an issue or crisis presents itself, a department within BIA addresses the problem, maybe with consultation with other departments. The Wind River ARMP has outlined the governance structure on the reservation and has identified goals, objectives and policies upon which to act, either proactively or reactively. In either case, the ARMP provides an integrated direction upon which the reservation will follow. The use of a geographic information system will assist in incorporating up-to-date spatial data on land use, environment and socio-economic factors for analysis (Wong \& Watkins, 2009). The ARMP reflects a unified decision-making process by the two tribes on the reservation and provides a mutually agreed upon agricultural resource management plan to enhance agriculture and economic development for the WRIR.

\section{Conflicts of Interest}

The authors declare no conflicts of interest regarding the publication of this paper.

\section{References}

Anderson, J. E. (2003). Public Policymaking (5th ed.). Boston, MA: Houghton Mifflin Company.

Bonogofsky, A. (2017). Through the Lens Bison Return to the Wind River. Wyofile. https://www.wyofile.com/lens-bison-return-wind-river

Brown, W. G. (1993). Structural Style of Laramide Basement-Cored Uplifts and Associated Folds. In A. W. Snoke, J. R. Steidtmann, \& S. M. Roberts (Eds.), Geology of Wyoming, Vol. I Geological Survey of Wyoming Memoir, No. 5, Laramie (pp. 312-371). Laramie, WY: Wyoming Geological Survey.

Census Bureau (2017). American Community Survey, 2013-2017. https://data.census.gov/cedsci/map?q=American\%20Community\%20Survey,\%202013$2017 \& g=\&$ hidePreview $=$ false \&table $=$ B02010\&tid $=$ ACSDT1Y2017.B02010\&y $=2017 \% 3$

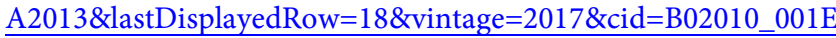

Colville Reservation (2015). Agricultural Resource Management Plan for the Colville Reservation. https://www.colvilletribes.com/irmp

Confederated Salish and Kootenai Tribes (2019). Confederated Salish and Kootenai Tribes of the Flathead Reservation, Comprehensive Resources Plan, Vol. 1 and Vol. 2. http://www.csktribes.org/natural-resources/tld

Daher, B. T., \& Mohtar, R. H. (2015). Water-Energy-Food (WEF) Nexus Tool 2.0: Guiding Integrative Resource Planning and Decision-Making. Water International, 40, 748 771. https://doi.org/10.1080/02508060.2015.1074148 
Fletcher, M. L. M. (2011). American Indian Tribal Law. Wolters Kluwer Law \& Business, New York: Aspen Publishers.

Gliessman, S. R. (1998). Agroecology: Ecological Processes in Sustainable Agriculture. Chelsea, MI: Ann Arbor Press.

Hazlitt, L., Nowlin, L., \& Phipps, K. (2013). The Wind River Indian Reservation: Interpretive Plan for the Eastern Shoshone and the Northern Arapaho. Cheyenne, WY: Wyoming State Historic Preservation Office.

Kalt, J., \& Singer, J. (2004). Myths and Realities of Tribal Sovereignty: The Law and Economics of Indian Self-Rule. Joint Occasional Papers of Native Affairs, No. 2004-03, Udall Center for Studies in Public Policy, the University of Arizona and the Harvard Project on American Indian Economic Development, Cambridge, MA: The Harvard Project on American Indian Economic Development.

https://doi.org/10.2139/ssrn.529084

Lachapelle, P. R., McCool, S. F., \& Patterson, M. E. (2003). Barriers to Effective Natural Resource Planning in a "Messy" World. Society and Natural Resources, 16, 473-490. https://doi.org/10.1080/08941920309151

Navajo Nation (2019). Division of Natural Resources, Department of Agriculture. http://www.agriculture.navajo-nsn.gov/

Patton, C. V., \& Sawicki, D. S. (1993). Basic Methods of Policy Analysis and Planning (2nd ed.). Englewood Cliffs, NJ: Prentice Hall.

Petak, W. J. (1980). Environmental Planning and Management: The Need for an Integrative Perspective. Environmental Management, 4, 287-295.

https://doi.org/10.1007/BF01869422

Pevar, S. L. (2012). The Rights of Indians and Tribes (4th ed.). Oxford: Oxford University Press.

Pyramid Lake Reservation (2011). Pyramid Lake Economic Development Plan (Vol. 1). http://plpt.nsn.us/econdev/index.html

Singletary, L., Emm, S., Brummer, F. A., Hill, G. C., Lewis, S., \& Hebb, V. (2015). Results of an Assessment to Identify Potential Barriers to Sustainable Agriculture on American Indian Reservations in the Western United States. The Journal of Agricultural Education and Extension, 22, 375-387. https://doi.org/10.1080/1389224X.2015.1074591

So, F., \& Getzel, J. (1988). The Practice of Local Government Planning (2nd ed.). Washington DC: International City Management Association.

Sundriyal, R. C., \& Dollo, M. (2013). Integrated Agriculture and Allied Natural Resource Management in Northeast Mountains-Transformations and Assets Building. Agroecology and Sustainable Food Systems, 37, 700-726. https://doi.org/10.1080/10440046.2012.720655

US Constitution, Article I. $\mathfrak{S} 8$, to Regulate Commerce with Foreign Nations, and among the Several States, and with the Indian Tribes. https://www.law.cornell.edu/constitution/articlei

US Constitution, Article II. S2, He [The President] Shall Have Power, by and with the Advice and Consent of the Senate, to Make Treaties, Provided Two Thirds of the Senators Present Concur. https://www.law.cornell.edu/constitution/articleii

US Department of Agriculture (2014). National Agricultural Statistics Service, 2014, Summary Table 1-Major Uses of Land, by Region and State, United States. https://www.ers.usda.gov/data-products/major-land-uses/major-land-uses/\#Summary \%20tables

US Department of Agriculture (USDA) (2019). National Agricultural Statistics Service, 
2019, Census of Agriculture, 2017: American Indian Reservations, Vol. 2, Subject Series, Part 5, $A C-17-S-5$. Washington DC.

US Department of Agriculture (USDA) (2012). Natural Resources Conservation Service, National Resource Inventory (2012) Land Use.

https://www.nrcs.usda.gov/wps/portal/nrcs/main/national/technical/nra/geo

US Department of Interior (2019). Bureau of Indian Affairs, Trust Services, Division of Natural Resources, Branch of Agriculture and Rangeland Management.

https://www.bia.gov/bia/ots/division-natural-resources/branch-agriculture-and-rangel and-development

US Fish and Wildlife Service (2017). Bison Return to Wind River Reservation. Fish and Wildlife News.

https://www.fws.gov/home/fwn/pdf/Spring\%20'17_web-ready.pdf

US Senate (2014). Irrigation Project in Indian Country. S. Hrg. Report No. 113-505. https://www.govinfo.gov/content/pkg/CHRG-113shrg91750/html/CHRG-113shrg9175 $\underline{0 . h t m}$

US Supreme Court (1989). Big Horn Adjudication, 110 S.Ct. 28, 106 L.Ed. 2 d 639 (1989).

Valentin, A., \& Spangenberg, J. H. (2000). A Guide to Community Sustainability Indicators. Environmental Impact Assessment Review, 20, 381-392. https://doi.org/10.1016/S0195-9255(00)00049-4

Walthall, C. L. et al. (2012). Climate Change and Agriculture in the United States: Effects and Adaptation. USDA Technical Bulletin 1935, Washington DC.

Wilkins, D. E. (1997). American Indian Sovereignty and the US Supreme Court: The Masking of Justice. Austin, TX: University of Texas Press.

Wind River Indian Reservation (1993). Wind River Indian Reservation Water Code, 1993. Office of Tribal Water Engineer, Ft. Washakie, WY: Wind River Indian Reservation.

Wind River Indian Reservation (2018). Agriculture Resource Management Plan; Wind River Indian Reservation. Office of Tribal Water Engineer, Ft. Washakie, WY: Wind River Indian Reservation.

Wong, C., \& Watkins, C. (2009). Conceptualizing Spatial Planning Outcomes: Towards and Integrative Measurement Framework. Town Planning Review, 80, 481-516. https://doi.org/10.3828/tpr.2009.8

Zaferatos, N. C. (2015). Planning the American Indian Reservation: From Theory to Empowerment. Syracuse, NY: Syracuse University Press.

Zautra, A., Hall, J., \& Murray, K. (2008). Community Development and Community Resilience: An Integrative Approach. Community Development, 39, 130-147. https://doi.org/10.1080/15575330809489673 